\title{
CHEMICAL CONSTITUENTS AND HEPATOPROTECTIVE EFFECT OF CASSIA OCCIDENTALIS L. CULTIVATED IN EGYPT
}

\author{
HANAA M. SAYED ${ }^{1}$; MAHMOUD A. RAMADAN ${ }^{1}$; MANAL M. SAYED ${ }^{2}$; SARY KH. ABD \\ ELGHAFFAR ${ }^{3}$ and HEBA H. SALEM ${ }^{1}$ \\ ${ }^{1}$ Department of Pharmacognosy, Faculty of Pharmacy, Assiut University, Assiut 71526, Egypt. \\ ${ }^{2}$ Department of Chemistry, Animal Health Research Institute, Assiut Lab., Egypt. \\ ${ }^{3}$ Department of pathology and Clinical Pathology, Faculty of Vet. Med. Assiut University, Assiut 71526, Egypt.
}

Received: 31 March 2016 ; Accepted: 30 April 2016

\begin{abstract}
This study was designed to investigate the hepatoprotective effects of the different successive extractives of the aerial parts of Cassia occidentalis L., on carbon tetrachloride $\left(\mathrm{CCL}_{4}\right)$ induced hepatotoxicity in adult Wistar rats. Sixty-six male albino rats were divided into eleven groups. First group received Tween only and served as control group. The second group injected with $\mathrm{CCL}_{4}(1: 1)$ in olive oil, at a dose of $2 \mathrm{ml} / \mathrm{kg} \mathrm{B}$.W. The third group injected with $\mathrm{CCL}_{4}$ in the same dose and Silymarin $(25 \mathrm{mg} / \mathrm{kg})$ orally for 7 days and served as reference group. Groups from four to eleven served as test groups injected with $\mathrm{CCL}_{4}$ in the same previous dose in addition to oral daily administration by one of either 200 or $400 \mathrm{mg} / \mathrm{kg} \mathrm{B}$.W. from each of the four extractives of Cassia occidentalis (total methanolic, chloroform, ethyl acetate and $n$ - butanol extracts). Treatment started one day after the injection of $\mathrm{CCl}_{4}$ and extended for two weeks. Parameters for liver function tests: Aspartate Aminotransferase (AST), Alanine Aminotransferase (ALT) and Bilirubinas as well as kidney function tests: Serum urea and Creatinine were determined spectrophotometrically. The different extractives of $C$. occidentalis L. showed improvement in both liver and kidney function indices, while ethyl acetate exteractive either in 200 or $400 \mathrm{mg} / \mathrm{kg} \mathrm{B.W.,} \mathrm{showed} \mathrm{the} \mathrm{best} \mathrm{results.} \mathrm{Histopathology} \mathrm{of} \mathrm{liver} \mathrm{tissue} \mathrm{specimens} \mathrm{supported} \mathrm{these} \mathrm{results.} \mathrm{The}$ biologically guided fractionation of $C$. occidentalis L. methanolic extract, revealed that the ethyl acetate fraction exhibited a significant dose dependant protective effect on both liver and kidney. The ethyl acetate fraction revealed activity approached that of silymarin (a known hepatoprotective agent). Chromatographic fractionation of the ethyl acetate fraction afford 6 purified compounds, identified on the basis of chemical and spectroscopic analysis as: naringenin (1), quercetin (2), 1,8-dihydroxy anthraquinone (3), 1,3,8-trihydroxy anthraquinone (4), chrysoeriol-7-O-rutinoside (5) and rutin (6). The isolated phenolics probably account for the hepatoprotective effect of the extract.
\end{abstract}

Key words: Chemical Constituents, Hepatoprotective, Cassia Occidentalis, Liver and kidney Function tests, rats.

\section{INTRODUCTION}

Liver diseases are considered a global problem especially in developing countries including Egypt. Hepatitis, viral infection, food additives, alcohol, toxic industrial chemical as well as air and water pollutants are the major risk factor of liver toxicity (Khan et al., 2012). Treatment of liver diseases via synthetic medication is usually disappointing due to its sever undesirable effect upon prolonged administration. Therefore, herbal products gain more interest in this issue and most recent studies aim to characterize the health promoting properties of many plants, especially those rich in phenolics that known

Corresponding author: Dr. SARY KH. ABD ELGHAFFAR E-mail address: sary64@windowslive.com

Present address: Department of pathology and Clinical Pathology, Faculty of Vet. Med. Assiut University, Assiut 71526, Egypt. to possess hepatoprotective and anti-inflammatory potencies.

Cassia is a genus of 40 species belonging to family Fabaceae, subfamily Caesalpinoideae (Tackhol, 1974). C. occidentalis L. (Coffee senra, Negro Coffee) as an Indian perennial diffuse under shrub, is used in several traditional medicine to cure various disease (Khare, 2007). This plant possess antibacterial, anthelmintic (Shao et al., 2013), antifungal, antiviral (Cong et al., 2014), antispasmodic, analgesic, antipyretic (Nakamura et al., 2014), antiplatelet aggregation, antihistamine release, hepatoprotective and neuroprotective (Kim et al., 2007 and Sung et al., 2004). Phytochemical studies of $C$. occidentalis reveled the presence of diversity of constituents including tannins, saponins, 
flavonoids, terpenes and anthraquinones (Bukhari et al., 2014 and Yadava et al., 2012).

Carbon tetrachloride $\left(\mathrm{CCl}_{4}\right)$ is one of the chemicals which cause liver damage through lipid peroxidation and oxidative stress (Moreira et al., 2014). $\mathrm{CCl}_{4}$ is a suitable chemical to induce oxidative liver toxicity in experimental animal model and its toxic effects was extensively studied by several investigators (AlDbass et al., 2012 and Azeem et al., 2010). In recent literatures it is documented that natural drugs with antioxidant potential can protect the liver from damage caused by $\mathrm{CCl}_{4}$ (Andritoiu et al., 2014; Shaker et al., 2010 and Sanmugapriya and Vankataraman 2006).

The current study was planned to evaluate the hepato and kidney protective activities of the fractionated methanolic extract of the aerial part of $C$. occidentalis L. as well as, to isolate and identify the components of the potent extractive.

\section{MATERIALS AND METHODS}

\section{1- Plant Material:}

Aerial parts of $C$. occidentalis $\mathrm{L}$. were collected in June 2013 from plants cultivated in the Experimental Station of Medicinal Plants, Faculty of Pharmacy, Assiut University. The plant was kindly authenticated by Prof. Dr. A.A. Fayed, Professor of Plant Taxonomy, Faculty of Science, Assiut University. Voucher specimen of the plant material was deposited at the Herbarium of Pharmacognosy Department, Faculty of Pharmacy, Assiut University.

\section{2- Plant Extraction:}

Air dried powdered aerial parts of $C$. occidentalis $\mathrm{L}$. $(3 \mathrm{~kg})$ was extracted by percolation with $80 \%$ methanol (4x6 L). The resulting methanolic extract was evaporated under vacuum, at a temperature not exceeding $40^{\circ} \mathrm{C}$. The concentrate $(300 \mathrm{gm})$ was suspended in distilled water $(600 \mathrm{ml})$, transferred to a separating funnel and subjected to successive several solvent fractionation using $\mathrm{n}$ - hexan, chloroform $\left(\mathrm{CHCl}_{3}\right)$, ethyl acetate (EtOAc) and $n$-butanol. The different extractives were concentrated separately under reduced pressure to give $65,35,25$ and $8 \mathrm{gm}$, respectively. The remaining aqueous extract was kept for further study (Harborne, 1973).

\section{3- Instruments and Chemicals:}

Nuclear magnetic resonance (NMR) spectra were recorded on Bruker Spectrophotometer at $400 \mathrm{MHz}$ for ${ }^{1} \mathrm{H}$ and $100 \mathrm{MHz}$ for ${ }^{13} \mathrm{C}$ NMR. Digital VIS/Ultraviolet Spectrophotometer was recorded on Cecil, Cambridge, England. Olympus microscope CX31, Japan and Camera (Olympus, Camedia, C5060, Japan) were also used.
All chemicals and solvents were of analytical grade. Silica gel $\mathrm{G}_{60}$ (Prolabo, India) for column chromatography, precoated silver gel plats $G_{60} F_{254}$ (Aluminum sheets, E-Merck, Germany), for thin layer chromatography (TLC). The biochemical kits were purchased from Bio-diagnostics, Cairo, Egypt.

\section{4- Experimental Animals:}

Sixty-six male Wistar albino rats (120-150 g) were obtained from the Animal House, Faculty of Medicine, Assiut University. All animals were acclimatized to the laboratory conditions, kept in controlled environment of air and temperature for 15 days before starting the experiments with access of water and diet ad Libitum.

\section{5- Acute Toxicity Study of Plant Extract:}

Three groups of rats ( 8 rats, each) were examined for the acute toxicity of the plant extract. One oral dose of $C$. occidentalis methanolic extract at concentrations of 200, 400 and $800 \mathrm{mg} / \mathrm{kg} \mathrm{B.W}$. were administered to rats. The mortality rate was calculated 24 hours after administration. The total methanolic extract of $C$. occidentalis aerial parts did not show any signs of toxicity and mortality up to 4 $\mathrm{g} / \mathrm{kg} \mathrm{B.W.} \mathrm{according} \mathrm{to} \mathrm{Lorke} \mathrm{(1983).}$

\section{6- Experimental Design:}

C. occidentalis different extractives (5 g, each) were suspended in Tween in distilled water at the appropriate concentration prior to oral treatment. The administration regimen was started one day after the injection of $\mathrm{CCl}_{4}$ and extended for two weeks. Sixtysix male Wistar albino rats were divided into 11 groups (6 animals, each).

Group 1: (Control group) received Tween only.

Group 2: $\left(\mathrm{CCl}_{4}\right.$ group) injected (I.P.) with one dose of $\mathrm{CCl}_{4}$ in olive oil (1:1) $2 \mathrm{mg} / \mathrm{kg} \mathrm{B.W}$. according to Lutz et al., (2003).

Group 3: (Silymarin reference group) injected (I.P.) with $\mathrm{CCl}_{4}$ in the same dose and followed by Silymarin (25 mg/kg b.wt.) orally for 7 days according to Mohamed (2013).

Groups 4-11: Served as testing groups and injected with $\mathrm{CCl}_{4}$ in the same previous dose and followed by oral daily administration by one of either 200 or 400 $\mathrm{mg} / \mathrm{kg} \mathrm{B.w}$. from each of the four extractives. The treatment started one day after the injection of $\mathrm{CCL}_{4}$ and extended for 2 weeks at the same time for the same duration.

\section{7- Serum Sample Preparation:}

Blood was collected from the retro-orbital plexus into clean free test tubes. Serum was prepared after 
centrifugation of the blood samples at 3000 r.p.m for 10 minutes and stored at $-20^{\circ} \mathrm{C} \mathrm{C}$ for further estimation of liver and kidney function tests.

\section{8- Biochemical Estimations:}

Serum AST, ALT and bilirubin as well as serum urea and creatinine were measured by using the appropriate test kits (Bio- diagnostics, Cairo, Egypt) spectrophotometrically. This was done according to the standard protocol of the suppliers.

\section{9- Histopathological Examination:}

Tissue specimens from liver were fixed in $10 \%$ neutral buffered formalin, dehydrated in a graded ethyl alcohol series, cleared with methyl benzoate and embedded in paraffin wax. Sections of $5 \mu \mathrm{m}$ were cut and stained with haematoxylin and eosin (Bancroft et al., 1996). Stained sections were examined under light microscope and photographed using digital camera.

\section{0- Statistical Analysis:}

Data are expressed as mean \pm SE for all parameters. The data were analyzed using Graph Pad Prism Data Analysis program software package (Graph Pad Software, Inc., San Diago CA, USA) for multiple comparisons, one-way analysis of variance (ONEWAY-ANNOVA) test was used.

11- Isolation of Ethyl Acetate Extractive Contents: Fractionation of the ethyl acetate extractive (10 g) was done on silica gel column $(150 \times 5 \mathrm{~cm}, 400 \mathrm{~g})$ and eluted successively with $\mathrm{CH}_{2} \mathrm{Cl}_{2}$-methanol gradient to give several fractions screened by TLC and similar fractions were combined to afford four fractions (IIV) $(2,1.5,3$ and $2.5 \mathrm{~g}$, respectively). Fraction I (2 g) was rechromatographed on silica gel column (100x2 $\mathrm{cm} / 80 \mathrm{~g}$ ) with gradient elution using $\mathrm{CH}_{2} \mathrm{Cl}_{2}-\mathrm{MeOH}$ in $2 \%$ increments to yield compounds (1) and (2). Fraction II (1.5 g) was rechromatographed on silica gel column $(100 \times 2 \mathrm{~cm}, 60 \mathrm{~g})$ with gradient elution using $\mathrm{CH}_{2} \mathrm{Cl}_{2}-\mathrm{MeOH}$ in $1 \%$ increments to yield compounds (3) and (4). Fraction III (3 g) were rechromatographed on silica gel column $(100 \times 2,120$ g), with gradient elution using $\mathrm{CH}_{2} \mathrm{Cl}_{2}-\mathrm{MeOH}$ in $1 \%$ increment to yield compound (5) and (6). Fraction IV showed mixture of minor spots, was kept for further investigation.

\section{RESULTS}

\section{I- Biochemical Study:}

Analysis of serum parameters of liver function tests (Table 1) demonstrated a decrease in serum concentration of ALT, AST and total bilirubin in groups which received $\mathrm{CCl}_{4}$ and treated either with total methanolic extract or different extractives of $C$. occidentalis $L$. when compared with the group which received $\mathrm{CCl}_{4}$ only.
The two groups which treated with EtoAc extractive (200 \& $400 \mathrm{mg} / \mathrm{kg}$ B.W.) showed the best improvement in liver function parameters in which there was marked significant decrease in ALT, AST and total bilirubin concentractions. Comparing this improvement in liver function parameters with those of sylimarin treated group, no significant changed could be detected. Groups which treated with $200 \mathrm{mg}$ $/ \mathrm{kg} \mathrm{B.W}$. of $\mathrm{CHCl}_{3}$ and $200 \& 400 \mathrm{mg} / \mathrm{kg} \mathrm{B.W}$. of nbutanol extractive showed non-significant decrease in ALT values.

Analysis of serum parameters of kidney function tests (Table 2) showed non-significant decrease in serum urea values in groups which received $\mathrm{CCl}_{4}$ and treated with all extractives when compared with those of the group which received $\mathrm{CCl}_{4}$ alone.

Groups which treated with EtoAc extractive (200 \& $400 \mathrm{mg} / \mathrm{kg} \mathrm{B}$. W.) showed a significant decrease in urea concentration when compared with that of $\mathrm{CCl}_{4}$ alone. In addition, no significant changed in urea concentration could be detected in comparison with that of Tween and Silymarin groups.

Concerning serum creatinine level in groups which treated with $200 \& 400 \mathrm{mg} / \mathrm{kg} \mathrm{B}$.W. of EtOAc extractive, significant decrease was detected on comparison with that of $\mathrm{CCl}_{4}$ received group. In addition, no significant changes could be recognized in serum creatinine level when compared with those of Tween and Silymarin groups. Other groups which treated with total methanolic, $\mathrm{CHCl}_{3}$ and n-butanol extractives showed non-significant decrease in serum creatinine level in comparison with $\mathrm{CCl}_{4}$ received group.

\section{Histopathological Examination:}

Microscopic examination of the liver sections of negative control group (Tween) revealed normal histological appearance of the liver tissue with normal hepatolobuler architecture contained central vein and regular hepatic cell cords (Fig. 1A), while that from reference group (Silymarin plus $\mathrm{CCl}_{4}$ ), showed mild vacuolar degeneration of the hepatocytes (Fig. 1B). In $\mathrm{CCl}_{4}$ treated group the hepatocytes showed marked fatty degeneration with appearance of small and large cytoplasmic vacuoles (Fig. 1C). In group received $\mathrm{CCl}_{4}$ along with $200 \mathrm{mg}$ total methanolic extract, the liver cells showed moderate fatty degeneration (Fig. 1D), while in group treated with $400 \mathrm{mg}$ total methanolic extract, the hepatocytes surrounding the central vein showed minute foci of necrosis (Fig. 2A). In the group treated with $200 \mathrm{mg}$ and $400 \mathrm{mg} \mathrm{CHCl}_{3}$ extractive, the hepatocytes showed very mild vacuolar degeneration (Fig. 2B\&C). Liver examination of group treated with $200 \mathrm{mg}$ EtOAc extractive showed normal hepatocytes with vesicular 
nuclei and acidophilic cytoplasm (Fig. 2D), while in $400 \mathrm{mg}$ EtOAc extractive treated group the liver showed congestion of the central vein with very mild vacuolar degeneration of the hepatocytes (Fig. 3A). In $n$-butanol extractive $200 \mathrm{mg}$ treated group, the liver showed marked vacuolar degeneration of the hepatocytes and periaciner necrobiosis (Fig. 2B), while in group received $400 \mathrm{mg} n$-butanol extractive, the liver showed congestion of the central vein with marked vacuolar degeneration of the hepatocytes (Fig. 3C).

\section{Isolated Compounds:}

Fractionation of the ethyl acetate extractive of the methanolic extract of $C$. occidentalis $\mathrm{L}$. that showed significant hepatoprotective effect resulted in isolation of 6 phenolic compounds (Fig. 4). All of them were identified basically on chromatographic, chemical and spectroscopic analysis as well as through comparison with published data.

Compound (1) was obtained as yellow amorphous powder (20 mg, $\mathrm{MeOH})$, attained deep purpule colour under $\mathrm{UV}$ and a yellow to orange colour with $\mathrm{AlCl}_{3}$ spray. UV $\lambda_{\max } \mathrm{nm}: \mathrm{MeOH}(287,326)$, +NaOMe $(245,323),+\mathrm{NaOAc}(284,323),+\mathrm{NaOAc} / \mathrm{H}_{3} \mathrm{BO}_{3}$ (290, 390), $+\mathrm{AlCl}_{3}(312,382),+\mathrm{AlCl}_{3} / \mathrm{HCl}(305$, 372). ${ }^{1} \mathrm{H}$ NMR (400 MHz, DMSO- $\left.d_{6}\right) \delta$ ppm: 5.42 $(1 \mathrm{H}, \mathrm{dd}, \mathrm{J}=14.4,2.4, \mathrm{H}-2), 3.25$ (1H, dd, $\mathrm{J}=12.8,3.2$, $\mathrm{H}-3 \mathrm{a}), 2.70(1 \mathrm{H}, \mathrm{dd}, \mathrm{J}=12.8,3.2, \mathrm{H}-3 \mathrm{~b}), 5.86(2 \mathrm{H}, \mathrm{s}$, H-6,8), $6.79\left(2 \mathrm{H}, \mathrm{d}, \mathrm{J}=8.4, \mathrm{H}-3^{\prime}, 5^{\prime}\right), 7.31(2 \mathrm{H}, \mathrm{d}, \mathrm{J}=$ 8.4, H-2',6'), 12.14 (1H, s, 5-OH). ${ }^{13} \mathrm{C}$ NMR (100 MHz, DMSO- $\left.d_{6}\right) \delta$ ppm: C-2 (78.88), C-3 (42.41), C4 (196.81), C-5 (163-39), C-6 (96.28), C-7 (163.94), C-8 (95.46), C-9 (158.15), C-10 (102-19), C-1' (129.32), C-2',6' (128.80), C-3',5' (115.63),C$4^{\prime}(167.22)$. The above mentioned data is in agreement with that reported for naringenin (Mabry et al., 1970 and Agrawal (1989). This is the first report for its isolation from the studied plant.

Compound (2) was obtained as yellow amorphous powders $(20 \mathrm{mg}, \mathrm{MeOH})$, attained yellow colour under $\mathrm{UV}$ and intensified after $\mathrm{AlCl}_{3}$ spray. $\mathrm{UV} \lambda_{\text {max }}$ $\mathrm{nm}: \mathrm{MeOH}(255,370),+\mathrm{NaOMe}(275,425)$, $+\mathrm{NaOAc}$ (266, 390), +NaOAc/ $\mathrm{H}_{3} \mathrm{BO}_{3}$ (259, 385), $+\mathrm{AlCl}_{3}(272,425),+\mathrm{AlCl}_{3} / \mathrm{HCl}(261,423) \mathrm{nm} .{ }^{1} \mathrm{H}$ NMR (400 MHz, DMSO- $\left.d_{6}\right) \delta$ ppm: $6.18(1 \mathrm{H}, \mathrm{d}, \mathrm{J}=$ 2, $\left.\mathrm{H}_{6}\right), 6.4\left(1 \mathrm{H}, \mathrm{d}, \mathrm{J}=2, \mathrm{H}_{8}\right), 6.88\left(1 \mathrm{H}, \mathrm{d}, \mathrm{J}=8.4, \mathrm{H}_{5^{\prime}}\right)$, $7.53\left(1 \mathrm{H}, \mathrm{d}, \mathrm{J}=8.4, \mathrm{H}_{6^{\prime}}\right), 7.67\left(1 \mathrm{H}, \mathrm{d}, \mathrm{J}=2, \mathrm{H}_{2^{\prime}}\right)$. The above mentioned data is consistent with the literature data of quercetin (Mabry et al., 1970 and Agrawal 1989). It was previously isolated from the plant.

Compound (3) was obtained as yellowish orange (10 $\mathrm{mg}, \mathrm{MeOH})$. UV $\lambda_{\max } \mathrm{nm}: \mathrm{MeOH}(225,277,429) .{ }^{1} \mathrm{H}$ NMR (400 MHz, DMSO- $\left.d_{6}\right) \delta_{\mathrm{H}} \mathrm{ppm}: 7.83(2 \mathrm{H}, \mathrm{t}, \mathrm{J}=$ $8, \mathrm{H}-3,-6), 7.73(2 \mathrm{H}, \mathrm{d}, \mathrm{J}=8.4, \mathrm{H}-4,5), 7.40(2 \mathrm{H}, \mathrm{d}, \mathrm{J}=$
8.4, H-2,7), 11.94 (s, OH). ${ }^{13} \mathrm{C} \mathrm{NMR}(100 \mathrm{MHz}$, DMSO- $\left.d_{6}\right) \delta_{\mathrm{c}}$ ppm: C-1,8 (161.83), C-2,7 (124.90), C-3,6 (137.93), C-4,5 (119.78), C-8a,9a (133.81), C4a,5a (116.47), C-9 (191,62), C-10 (181.37). The above mentioned data is in agreement with that previously reported for 1,8-dihydroxy anthraquinone, which was previously isolated from the roots of the plant. (Chukwujekwu et al., 2006).

Compound (4) was obtained as yellowish orange (10 $\mathrm{mg}, \mathrm{MeOH}) .{ }^{1} \mathrm{H}$ NMR $\left(400 \mathrm{MHz}, \mathrm{DMSO}-d_{6}\right) \delta_{\mathrm{H}} \mathrm{ppm}$ : $7.77\left(1 \mathrm{H}, \mathrm{s}, \mathrm{H}_{2}\right), 8.13\left(1 \mathrm{H}, \mathrm{s}, \mathrm{H}_{4}\right), 7.75(1 \mathrm{H}, \mathrm{d}, \mathrm{J}=7.6$, $\left.\mathrm{H}_{5}\right), 7.83\left(1 \mathrm{H}, \mathrm{t}, \mathrm{J}=7.6, \mathrm{H}_{6}\right), 7.41\left(1 \mathrm{H}, \mathrm{d}, \mathrm{J}=8, \mathrm{H}_{7}\right)$, $11.98(\mathrm{OH}) .{ }^{13} \mathrm{C}$ NMR (100 MHz, DMSO- $\left.d_{6}\right) \delta_{\mathrm{c}} \mathrm{ppm}$ : $\mathrm{C}_{1}-1$ (161.5), C-2 (124.64), C-3 (165.92), C-4 (119.22), C-4a (134.24), C-5 (119.22), C-6 (138.13), C-7 (129.15), C-8 (161.83), C-8a (116.33), C-9 (191.62), C-9a (118.53), C-10 (181.37), C-10a (133.14). The above mentioned data is consistent with the literature data of 1,3,8-trihydroxy anthraquinone (Rogerio et al., 2008). It is the first report for its isolation from the plant.

Compound (5) was obtained as yellow amorphous powder (15 mg, MeOH) attained deep purple colour under UV and a yellow colour with $\mathrm{AlCl}_{3}$ spray. UV $\lambda_{\max } \mathrm{nm}: \mathrm{MeOH}(267,342),+\mathrm{NaOMe}(270,391)$, $+\mathrm{NaOAc}(269,346),+\mathrm{NaOAc} / \mathrm{H}_{3} \mathrm{BO}_{3}$ (269, 350), $+\mathrm{AlCl}_{3}(273,347),+\mathrm{AlCl}_{3} / \mathrm{HCl}(275,349,290) .{ }^{1} \mathrm{H}$ NMR (400 MHz, DMSO-d $d_{6} \delta$ ppm: $6.46(1 \mathrm{H}, \mathrm{s}, \mathrm{H}-$ 6), $6.76(1 \mathrm{H}, \mathrm{s}, \mathrm{H}-3), 6.82(1 \mathrm{H}, \mathrm{s}, \mathrm{H}-8), 7.13(1 \mathrm{H}, \mathrm{d}$, $\left.\mathrm{J}=8.4, \mathrm{H}-5^{\prime}\right), 7.44\left(1 \mathrm{H}, \mathrm{s}, \mathrm{H}-2^{\prime}\right), 7.57(1 \mathrm{H}, \mathrm{d}, \mathrm{J}=8.4$, H-6'), 5.08 (1H, d, J= 7.2, H-1') $4.53(1 \mathrm{H}, \mathrm{d}, \mathrm{J}=1.2$, H-1"'), $3.87\left(3 \mathrm{H}\right.$, s, $\left.\mathrm{OCH}_{3}\right), 3.17-5.45$ (m, sugar protons), 1.07 (3H, d, J=6, H-6"'), $12.93(1 \mathrm{H}, \mathrm{s}, 5-$ OH). ${ }^{13} \mathrm{C}$ NMR (100 MHz, DMSO- $\left.d_{6}\right) \delta$ ppm: C-2 (163.41), C-3 (104.29), C-4 (182.42), C-5 (161.67), C-6 (100.05), C-7 (164-66), C-8 (95.27), C-9 (157.42), C-10 (105.91), C-1' (123.34), C-2' (112.71), C-3' (151.78), C-4' (147.23), C-5' (119.42), C-6' (123.34), C-1" (100.37), C-2" (73.56), C-3" (76.06), C-4" (70.03), C-5" (76.72), C-6" (66.50), C-1"' (100.99), C-2"' (71.20), C-4'" (72.51), C-5"' (68.80), C-6"' (18.27). On the basis of the above mentioned data, compound (5) was elucidated as chrysoeriol-7O-rutinoside (Agrawal, 1989). It is the first report for its isolation from the plant.

Compound (6) was obtained as yellow amorphous powder (24 mg, MeOH) attained deep purple colour under UV and a yellow colour with $\mathrm{AlCl}_{3}$ spray. UV $\lambda_{\max } \mathrm{nm}: \mathrm{MeOH}(253,357),+\mathrm{NaOMe}(272,400)$, $+\mathrm{NaOAc}(272,380),+\mathrm{NaOAc} / \mathrm{H}_{3} \mathrm{BO}_{3} \quad(260,375)$, $+\mathrm{AlCl}_{3}(275,433),+\mathrm{AlCl}_{3} / \mathrm{HCl}(273,404) .{ }^{1} \mathrm{H}$ NMR (400 MHz, DMSO- $\left.d_{6}\right) \delta$ ppm: $6.19\left(1 \mathrm{H}, \mathrm{d}, \mathrm{J}=2, \mathrm{H}_{6}\right)$, $6.38\left(1 \mathrm{H}, \mathrm{d}, \mathrm{J}=2, \mathrm{H}_{8}\right), 6.84\left(1 \mathrm{H}, \mathrm{d}, \mathrm{J}=8.4, \mathrm{H}_{5^{\prime}}\right), 7.54$ $\left(1 \mathrm{H}, \mathrm{d}, \mathrm{J}=8.4, \mathrm{H}_{6^{\prime}}\right), 7.55\left(1 \mathrm{H}, \mathrm{d}, \mathrm{J}=2, \mathrm{H}_{2^{\prime}}\right), 5.34(1 \mathrm{H}$, $\left.\mathrm{d}, \mathrm{J}=7.2, \mathrm{H}_{1 "}\right), 3.05-5.33$ (m, sugar protons), 4.39 $\left(1 \mathrm{H}, \mathrm{d}, \mathrm{J}=0.5, \mathrm{H}_{1^{\prime \prime}}\right), 0.99\left(3 \mathrm{H}, \mathrm{d}, \mathrm{J}=6.3, \mathrm{H}_{6 " '}\right), 12.60$ 
(1H, s, 5-OH). ${ }^{13} \mathrm{C}$ NMR (100 MHz, DMSO-d 6$) \delta$ ppm: C-2 (156.88), C-3 (133.66), C-4 (177.78), C-5 (161.58), C-6 (99.16), C-7 (164-52), C-8 (94.11), C-9 (157.13), C-10 (104.37), C-1' (121.58), C-2' (115.65), C-3' (145.15), C-4' (148.82), C-5' (116.64), C-6' (122.09), C-1" (101.54), C-2" (74.49), C-3" (76.24), C-4" (70.40), C-5" (75.79), C-6" (67.41), C-1"" (101.13), C-2"' (70.77), C-3"' (70.95), C-4"' (72.25),
C-5"' (68.66), C-6"' (18.07). On the basis of the above mentioned evidence, compound (6) was elucidated as quercetin-3-O- $\alpha$ L-rhamnopyranosyl-(1-6)- $\beta$-Dglucopyranoside (rutin) (Mabry et al. and 1970, Agrawal, 1989). It is the first report for its isolation from the plant.

Table 1: Serum ALT (U/L), AST (U/L) and total bilirubin (mg/dL) values in different experimental groups.

\begin{tabular}{|c|c|c|c|c|c|c|c|c|c|c|c|}
\hline Parameters & Tween & Silymarin & $\mathrm{CCl}_{3}$ & $\begin{array}{l}\text { Total } \\
200\end{array}$ & $\begin{array}{l}\text { Total } \\
400\end{array}$ & $\begin{array}{c}\mathrm{CHCl}_{3} \\
200\end{array}$ & $\begin{array}{c}\mathrm{CHCl}_{3} \\
400\end{array}$ & $\begin{array}{c}\text { EtOAc } \\
200\end{array}$ & $\begin{array}{c}\text { EtOAc } \\
400\end{array}$ & $\begin{array}{c}\begin{array}{c}n- \\
\text { butanol }\end{array} \\
200\end{array}$ & $\begin{array}{c}n- \\
\text { butanol } \\
400\end{array}$ \\
\hline ALT & 18.78 & 22.23 & 36.24 & 28.35 & 28.75 & 31.18 & 28.80 & 26.75 & 24.83 & 33.69 & 35.41 \\
\hline Mean $\pm \mathrm{SE}$ & $\pm 1.06^{\mathrm{a}}$ & $\pm 1.29^{\mathrm{b}}$ & $\pm 2.02^{\mathrm{c}}$ & $\pm 1.30^{\mathrm{b}}$ & $\pm 1.66^{\mathrm{b}}$ & $\pm 1.85^{\mathrm{c}}$ & $\pm 1.55^{\mathrm{b}}$ & $\pm 0.89^{\mathrm{b}}$ & $\pm 2.55^{\mathrm{b}}$ & $\pm 1.43^{\mathrm{c}}$ & $\pm 2.41^{\mathrm{c}}$ \\
\hline AST & 44.61 & 51.53 & 78.33 & 59.42 & 58.68 & 57.28 & 54.21 & 56.95 & 55.94 & 59.69 & 59.05 \\
\hline Mean \pm SE & $\pm 1.46^{\mathrm{a}}$ & $\pm 1.89^{\mathrm{b}}$ & $\pm 2.30^{\mathrm{c}}$ & $\pm 1.62^{\mathrm{b}}$ & $\pm 1.15^{\mathrm{b}}$ & $\pm 1.16^{\mathrm{b}}$ & $\pm 0.70^{\mathrm{b}}$ & $\pm 0.52^{\mathrm{b}}$ & $\pm 1.81^{\mathrm{b}}$ & $\pm 1.17^{\mathrm{b}}$ & $\pm 0.96^{\mathrm{b}}$ \\
\hline $\begin{array}{l}\text { Total } \\
\text { bilirubin }\end{array}$ & 0.52 & 0.57 & 0.88 & 0.76 & 0.78 & 0.82 & 0.85 & 0.68 & 0.60 & 0.78 & 0.76 \\
\hline Mean \pm SE & $\pm 0.10^{\mathrm{a}}$ & $\pm 0.15^{\mathrm{a}}$ & $\pm 0.15^{\mathrm{b}}$ & $\pm 0.33^{\mathrm{c}}$ & $\pm 0.13^{\mathrm{c}}$ & $\pm 0.19^{c}$ & $\pm 0.09^{c}$ & $\pm 0.12^{\mathrm{a}}$ & $\pm 0.23^{\mathrm{a}}$ & $\pm 0.14^{\mathrm{c}}$ & $\pm 0.12^{\mathrm{c}}$ \\
\hline
\end{tabular}

Notes: Values are means bearing different superscripts within same raw were significantly different $(\mathrm{P} \leq 0.001)$.

Table 2: Serum urea $(\mathrm{mg} / \mathrm{dL})$ and creatinine $(\mathrm{mg} / \mathrm{dL})$ values in different experimental groups.

\begin{tabular}{|c|c|c|c|c|c|c|c|c|c|c|c|}
\hline Proups & Tween & Silymarin & $\mathrm{CCl}_{3}$ & $\begin{array}{l}\text { Total } \\
200\end{array}$ & $\begin{array}{l}\text { Total } \\
400\end{array}$ & $\begin{array}{c}\mathrm{CHCl}_{3} \\
200\end{array}$ & $\begin{array}{c}\mathrm{CHCl}_{3} \\
400\end{array}$ & $\begin{array}{c}\text { EtOAc } \\
200\end{array}$ & $\begin{array}{c}\text { EtOAc } \\
400\end{array}$ & $\begin{array}{c}n \text {-butanol } \\
200\end{array}$ & $\begin{array}{c}n \text {-butanol } \\
400\end{array}$ \\
\hline Urea & 20.78 & 29.3 & 55.9 & 50.35 & 40.75 & 38.8 & 34.08 & 29.05 & 27.03 & 46.60 & 43.01 \\
\hline Mean \pm SE & $\pm 0.96^{\mathrm{a}}$ & $\pm 0.82^{\mathrm{a}}$ & $\pm 0.76^{\mathrm{b}}$ & $\pm 1.30^{\mathrm{b}}$ & $\pm 0.66^{\mathrm{b}}$ & $\pm 0.85^{\mathrm{b}}$ & $\pm 1.05^{\mathrm{b}}$ & $\pm 0.89^{\mathrm{a}}$ & $\pm 2.55^{\mathrm{a}}$ & $\pm 1.43^{\mathrm{b}}$ & $\pm 1.41^{\mathrm{b}}$ \\
\hline Creatinine & 0.40 & 0.38 & 0.58 & 0.48 & 0.42 & 0.46 & 0.42 & 0.39 & 0.36 & 0.45 & 0.49 \\
\hline Mean $\pm \mathrm{SE}$ & $\pm 0.06^{\mathrm{a}}$ & $\pm 0.01^{\mathrm{a}}$ & $\pm 0.04^{\mathrm{c}}$ & $\pm 0.06^{\mathrm{c}}$ & $\pm 0.01^{\mathrm{c}}$ & $\pm 0.08^{\mathrm{c}}$ & $\pm 0.08^{\mathrm{c}}$ & $\pm 0.05^{\mathrm{a}}$ & $\pm 0.03^{\mathrm{a}}$ & $\pm 0.07^{\mathrm{c}}$ & $\pm 0.06^{\mathrm{c}}$ \\
\hline
\end{tabular}

Notes: Values bearing different superscripts within same raw were significantly different $(\mathrm{P} \leq 0.001)$. 

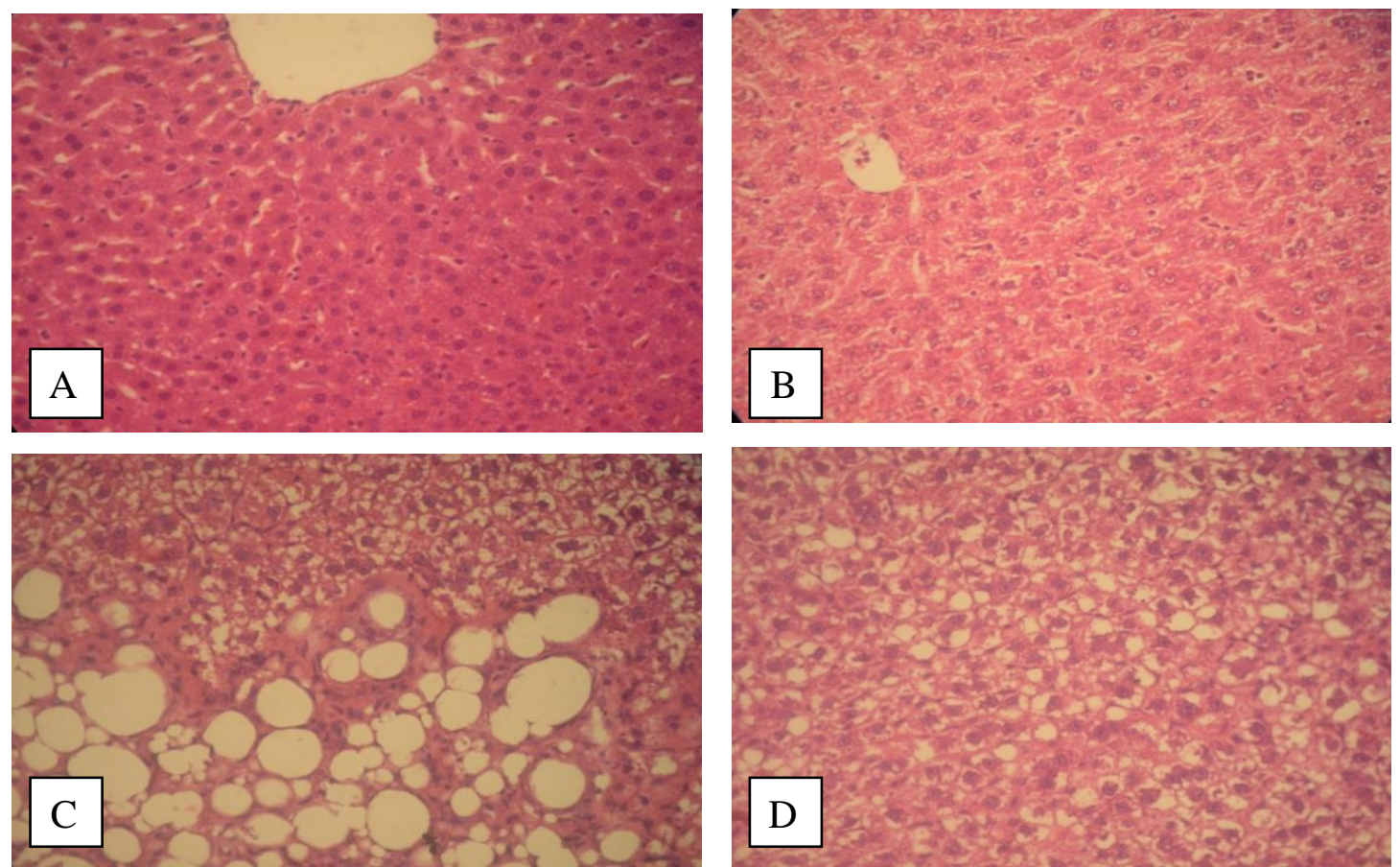

Fig.1: Photomicrograph liver section, (A) from negative control (Tween) group showing normal histological appearance, notice the central vein and hepatic cords. (B) from reference group (Silymarin) showing mild vacuolar degeneration of the hepatocytes. (C) from $\mathrm{CCl}_{4}$ group showing marked fatty degeneration in the hepatocytes. (D) from total methanolic extract $200 \mathrm{mg}$ treated group showing moderate fatty degeneration of the hepatocytes.
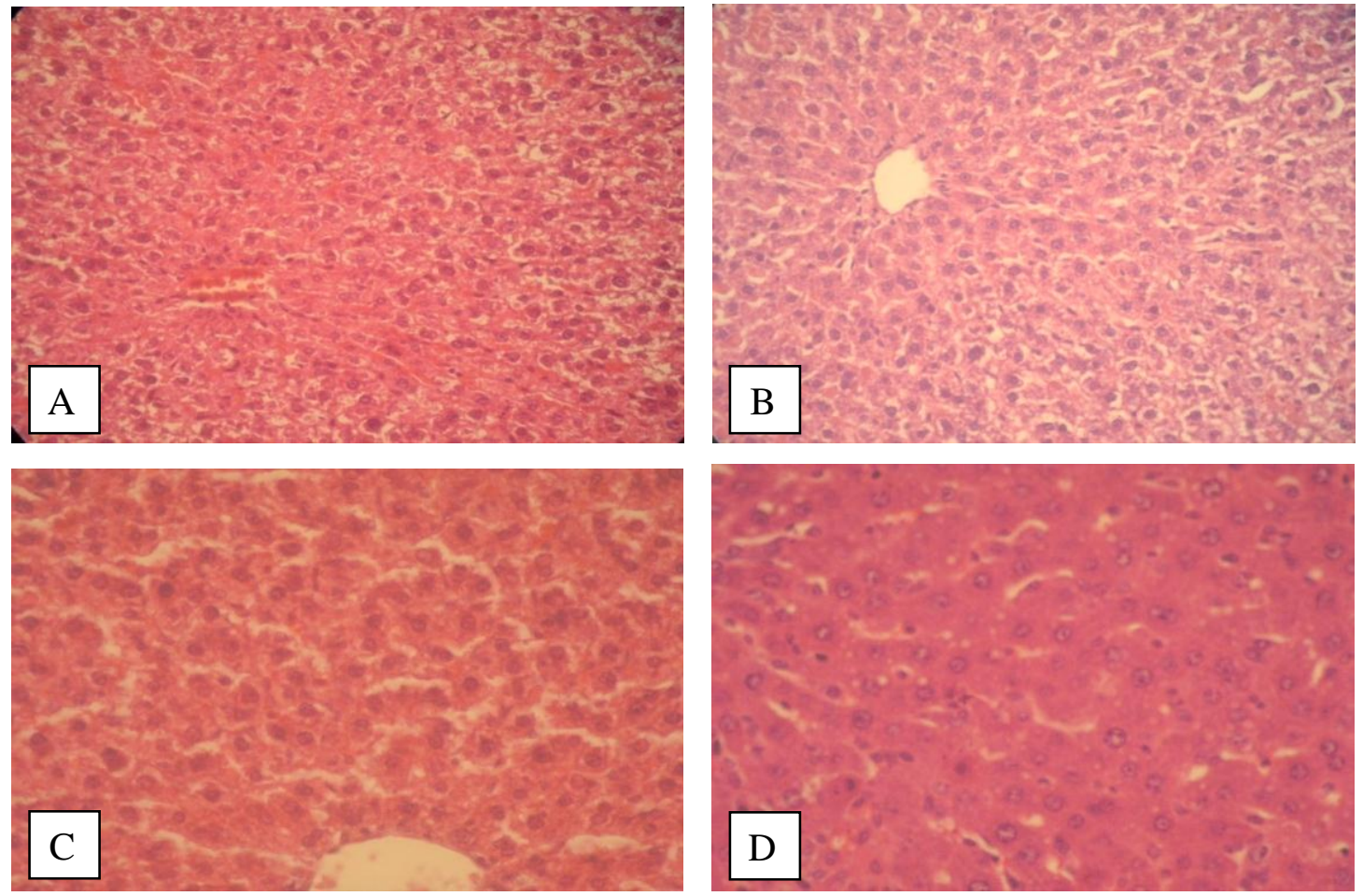

Fig.2: Photomicrograph liver section, (A) from total methanolic extract 400mg treated group showing minute foci of hepatocytes necrosis surrounding the centeral vein. (B) from $\mathrm{CHCl}_{3}$ extractive $200 \mathrm{mg}$ treated group showing very mild vacuolar degeneration of the hepatocytes. (C) from $\mathrm{CHCl}_{3}$ extractive $400 \mathrm{mg}$ showing very mild vacuolar degeneration of the hepatocytes. (D) from EtoAc extractive 200mg showing normal hepatocytes with vesicular nuclei and acidophilic cytoplasm. H\&E. X 40. 

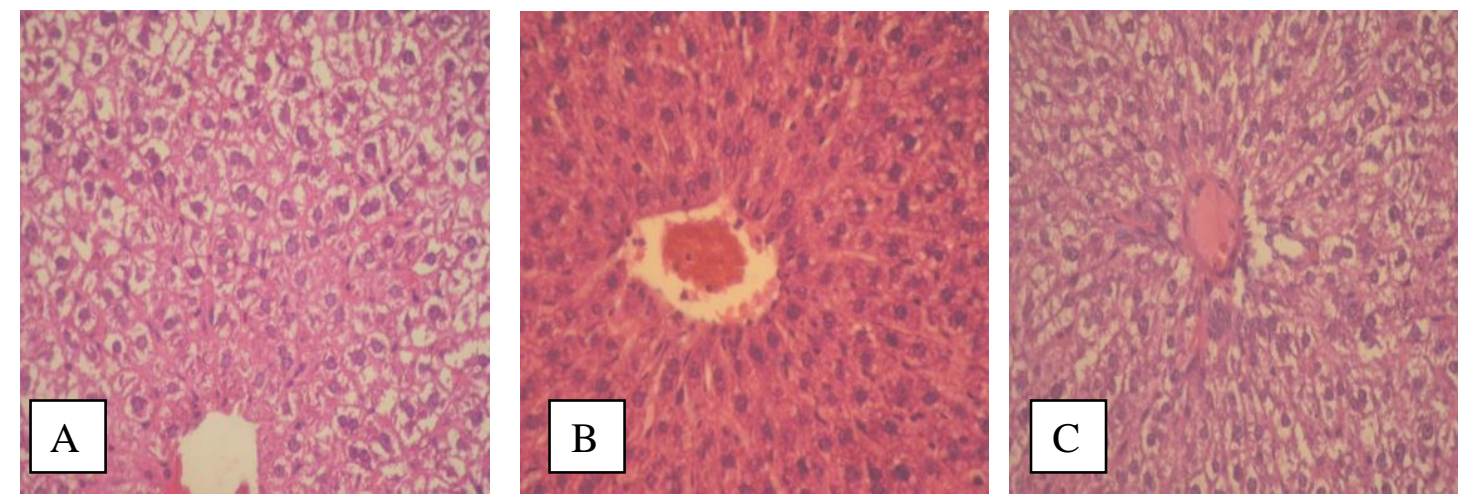

Fig.3: Photomicrograph of liver section (A) from EtoAc extractive 400mg treated group showing congestion of the centeral vein with very mild vacuolar degeneration of the hepatocytes. (B) from n-butanol extractive $200 \mathrm{mg}$ treated group showing marked vacuolar degeneration of the hepatocytes and periaciner necrobiosis. (C) from nbutanol extractive $400 \mathrm{mg}$ treated group showing congestion of the centeral vein and marked vacuolar degeneration of the hepatocytes. H\&E. X 40.

Fig. 4:<smiles>O=c1cc(-c2ccc(O)cc2)oc2cc(O)cc(O)c12</smiles>

(1)<smiles>O=C1c2cccc(O)c2C(=O)c2c(O)cccc21</smiles>

(3)<smiles>O=c1c(O)c(-c2ccc(O)c(O)c2)oc2cc(O)cc(O)c12</smiles>

(2)<smiles>O=C1c2cccc(O)c2C(=O)c2c(O)cc(O)cc21</smiles>

(4)<smiles>COc1cc(-c2cc(=O)c3c(O)cc(OC4OC5COC6OC(C)C(O)C(O)C(O)C(O)C6OC4C(O)C5O)cc3o2)ccc1O</smiles>

(5)<smiles>CC(O)C1OC2OC(Oc3c(-c4ccc(O)c(O)c4)oc4cc(O)cc(O)c4c3=O)OC1C(O)C(O)C(O)C(O)O2</smiles>

(6) 


\section{DISCUSSION}

Our study revealed that treatment with ethyl acetate extractive of Cassia occidentalis L. either in a dose 200 or $400 \mathrm{mg} / \mathrm{kg} \mathrm{B.W}$. gave the best results in the liver function parameters in the form of marked significant decrease in ALT, AST and total bilirubin concentrations in comparison with $\mathrm{CCl}_{4}$ treated group, and had no significant changes in values of ALT, AST and bilirubin in comparison with Silymarin treated group. Similarly, previous studies revealed significant results. Bhakta et al. (1999) studied the hepatoprotective effect of the $n$-heptan extractive of Cassia fistula leaves (400 mg/kg B.W.) in rats by inducing hepatoxicity with carbon tetrachloride: liquid paraffin $(1: 1)$. He found that the extract $(400 \mathrm{mg} / \mathrm{kg} \mathrm{B.W})$ has been showed to posses protective effect by lowering the serum levels of (SGOT and SGPT), bilirubin and alkaline phosphatase (ALP). Jafri et al. (1999) also studied the effect of aqueous ethanolic extract of Cassia occientalis leaves and reported an improvement in liver function parameters (AST, ALT and alkaline phosphatase) after liver damage induced by paracetamol in rats.

The histopathological examination of the liver in different treated groups demonstrated that $\mathrm{CCl}_{4}$ induced sever pathological changes either in the form of fatty changes or necrobiosis of the hepatocytes. These changes were subsided in Silymarin and other extractive treated groups. The treatment with ethyl acetate extractive of Cassia occidentalis aerial parts either in a dose 200 or $400 \mathrm{mg} / \mathrm{kg} \mathrm{B.W}$. gave the best improvement, in which the hepatic tissue appeared more or less normal. In Silymarin, methanolic extract and chloroform extractive treated groups, there were mild pathological changes in the form of congestion of vasculature and vacuolar degeneration of hepatocytes. While in the group which treated with $n$ butanol extractive, no histological improvement could be detected. From our results, it was clear that the histopathological findings of liver examination was positively correlated and supported the biochemical analysis of liver function parameters in different treated groups.

Our results of kidney function tests showed non significant decrease in serum urea values in all treated groups in comparison with $\mathrm{CCl}_{4}$ treated group except the groups which treated with 200 and $400 \mathrm{mg} / \mathrm{kg}$ B.W. EtOAc extractive showed significant decrease in urea concentration in comparison with $\mathrm{CCl}_{4}$ received group, and had no significant changes in comparison with Tween and Silymarin groups. There was significant decrease in serum creatinine levels in groupstreated with 200 and $400 \mathrm{mg} / \mathrm{kg} \mathrm{B.W.} \mathrm{of}$ EtOAc extractive groups in comparison with $\mathrm{CCl}_{4}$ received group, and showed no significant changes in comparison with Tween and Silymarin groups. The other groups (Total methanolic, $\mathrm{CHCl}_{3}$ and $n$-butanol extractive) showed non significant decrease in serum creatinine levels in comparison with $\mathrm{CCl}_{4}$ received group. Mirtes et al. (2011) demonstrated that oral administration with hydroalcoholic extract of Cassia occidentalis for 30 days $(0.10,0.50$ and $2.5 \mathrm{~g} / \mathrm{kg})$ in male and female rats did not changes the biochemical profile (creatinine and urea) which is good indicators of kidney functions and they reported that Cassia occidentalis extract did not induce any damage to the kidney and it is not toxic and safety for use by human. Also similar results was obtained by Hilaly et al. (2004). He found normal kidney function after oral sub-acute treatment by Cassia occidentalis extract. Fid'ele Ntchapda et al. (2015) revealed that subchronic treatment with aqueous extract of Cassia occidentalis leaves $400 \mathrm{mg} / \mathrm{kg} \mathrm{B.W}$. for 7 days in rats improved the kidney function index of urea and creatinine. The hepatoprotective and nephropotective effects Cassia occidentalis extracts could be attributed to its antioxidant activity (Usha et al., 2007 and Silva et. al., 2008). The histopathological findings in our results confirmed these effects. The treatment with ethyl acetate extractive of Cassia occidentalis either in a dose 200 or $400 \mathrm{mg} / \mathrm{kg} \mathrm{B.W}$. gave the best protection.

\section{CONCLUSION}

Cassia occidentalis ethyl acetate extractive have hepatoprotective and nephroprotective effects. This could be attributed to the antioxidant activity of its phenolic contents (compounds 1-6). Although the ethyl acetate extractive of Cassia occidentalis could be considered as a promising source of natural hepatoprotective agents, further application in medical practice should be confirmed by conveying pharmacological and placebo controlled clinical studies.

\section{REFERENCES}

Agrawal, P.K. (1989): Carbon-BNMR of Flovenoids. Elsevier Science B.V. Amsterdam, Oxford, Newyork, Tokyo.

Al-Dbass, AM.; Al-Daihan, SK. and Bhat, RS. (2012): Garicus blazei Murill as an efficient hepatoprotective and antioxidant agent against $\mathrm{CCl}_{4}$-induced liver injury in rats. Saudi J Biol Sci 19: 303-309.

Andritoiu, CV.; Andritoiu, V.; Cuciureanu, M.; NicaBadea, D. and Bibire N. Popa M. (2014): Effect of apithera-pyproducts against carbon tetrachloride induced toxicity in Wistar rats. Rom J. Morphol Embryol 55: 835-847.

Azeem, AK.; Mathew, M.; Nair, C. and Dilip, C. (2010): Hepatoprotective effect of Averrhoea caram-bola fruit extract on carbon tetrachloride induced hepatotoxicity in mice. Asian Pacific J. Trop Med. 610-613. 
Bancroft, TD.; Stevens, A. and Turner, DR. (1996): Theory and practice of histological technique, $4^{\text {th }}$ ed. Churchill, Livingstone, New York.

Bhakta, T.; Mukherjee, PK.; Mukherjee, K.; Banerjee, S.; Mandal, SC. and Saha, BP. (1999): Evaluation of hepatoprotective activity of Cassia fistula leaf extract. J. Ethnopharmacol. Sept; 66(3): 277-82.

Bukhari, NA.; Siddique, I.; Perveen, K.; Siddiqui, I. and Alwahibi, MS. (2014): Synthetic seed production and physio-biochemical studies in Cassia angustifolia Vahl. - a medicinal plant. Acta Biol Hung 65: 355-367.

Chukw ujekwu, J.C.; Coombes, PH.; Mulholland, DA. and Staden, J.V. Emodin (2006): An antibacterial anthraquinone from the roots of Cassia occidentalis. South African. Bot. 72(2) 295-97.

Cong, Q.; Shang, M.; Dong, Q.; Liao, W.; Xiao, F. and Ding, $K$. (2014): Structure and activities of a novel heteroxylan from Cassia obtusifolia seeds and its sulfated derivative. Carbohydrate Res. 393: 43-50.

Fid ele Ntchapda; Joseph Barama; David Romain Kemeta Azambou; Paul Faustin Seke Etet and Th'eophile Dimo. (2015): Diuretic and antioxidant activities of the aqueous extract of leaves of Cassia occidentalis (Linn.) in rat. Asian Pacific Journal of Tropical Medicine 1-9.

Harborne, J.B. (1973): Phytochemical Methods. Chapman and Hall. Ltd, London, Neewyourk, 2 nd Ed.,

Hilaly, J.E.; Israili, Z.H. and Lyoussi, B. (2004): Acute and chronic toxicological studies of Ajuga iva in experimental animals. Journal of Ethnopharmacology 91, 43-50.

Jafri, MA.; Jalis, SM.; Javed, K. and Singh, S. (1999): Hepatoprotective activity of leaves of Cassia occidentalis against paracetamol and ethyl alcohol in Rats. J. Ethnopharmacol. 66 (3): 355-61.

Khare, CP. (2007): Indian Medicinal plantsAyurveda an illustrated Dictionary, US: Springer.

Khan, RA.; Khan, MR.; Sahreen and Shah, S. (2012): Hepatopretective activity of Sonchus asper against carbon tetrachloride-induced injuries in male rats: A randomized controlled trial, BMC Comp Alt Med; 12:90-98.

Kim, D.H.; Yoon, B.H.; Kim, Y.W.; Lee, S.; Shin, B.Y.; Jung, J.W.; Ki, H.J.; Lee, Y.S.; Choi, J.S.; Kim, S.Y.; Lee, K.T. and Ryu, J.H. (2007): The seed extract of Cassia obtusifolia ameliorates learning and memory impairments induced by scopolamine or transient cerebral hypoperfusion in mice. J. Pharmacol Sci. 105: 82-93.

Lorke, D. (1983): Archives of Toxcology, 54(4), 257287.
Lutz W.D. Weber; Meinrad Boll and Andreas Stampfl (2003): Hepatotoxicity and mechanism of action of haloalkanes: carbon tetrachloride as a toxicological model. Crit. Rev. Toxicol. 33(2):105-36

Mabry, TJ.; Marham rk and Thomas, MB. (1970): The Systematic Identification of Flavonoids, Springer, New York.

Mirtes G.B. Silva; Ticiana. Aragão; Carlos F.B. Vasconcelos; Pablo A. Ferreira; Bruno A. Andrade; Igor M.A. Costa; João H. CostaSilva; Almir G. Wanderley and Simone S.L. Lafayette (2011): Acute and subacute toxicity of Cassia occidentalis L. stem and leaf in Wistar rats. Journal of Ethnopharmacology 136 341-346.

Mohamed, A.A. (2013): Phytochemichal study of polygonum bellardii all (F.Polygonaceae) and Gladiolus Segetum ker-gwal (F. iridaceae). Ph.D. Thesis in pharmaceutical science, Faculty of Pharmacy, Assiut University.

Moreira, PR.; Maioli, MA.; Medeiros, HCD.; Guelfi, M.; Pereira, FTV. and Mingatto, FE. (2014): Protective effect of bixinon carbon tetrachloride induced hepatotoxicity in rats. Biological Research 47: 49-

Nakamura, S.; Xu, F.; Ninomiya, K.; Nakashima, S.; Oda, Y. and Morikawa, T. (2014): Chemical structures and hepatoprotective effects of constituents from Cassia auriculata leaves. Chem. Pharm. Bull. (Tokyo) 62: 1026-1031.

Rogerio Nunes; dos Santos; Maria Goretti and Vasconcelos Silva. (2008): Constituinets auimicos Do Cauled De Senna reticulate wild (Leguminosae). Quim Nova Vol. 31 (8) 1979-81.

Sanmugapriya, E. and Venkataraman, S. (2006): Studies on hepatoprotective and antioxidant actions of Strychnos potatorum Linn. seeds on $\mathrm{CCl}_{4}$-induced acute hepatic injury in experimental rats. J. Ethnopharmacol. 105: 154-160.

Shao, F.; Chen, HJ.; Liu, RH.; Hou, YC.; Ren, G. and Huang, HL. (2013): Effects of heishunpian total alkaloids on Cassia acutifolia induced mice diarrhea and contraction of isolated intestinal smooth muscle in rats. Zhong Yao Cai 36: 1805-1809.

Shaker, E.; Mahmoud, H. and Mnaa, S. (2010): Silymarin, the antioxidant component and Silybum maria-num extracts prevent liver damage. Food Chem Toxicol. 48: 803-806.

Silva, CR.; Monteiro, MR.; Rocha, HM.; Ribeiro, AF.; Caldeira-de Araujo, A. and Leitao, AC. (2008): Assessment of antimutagenic and genotoxic potential of senna (Cassia angustifolia Vahl.) aqueous extract using in vitro assays. Toxicol. Vitro 22: 212-218.

Sung, BK.; Kim, MK.; Lee, WH.; Lee, DH. and Lee, HS. (2004): Growth responses of Cassia 
obtusifolia toward human intestinal bacteria. Fitoterapia 75: 505-509.

Tackholm, V. (1974): Students Flora of Egypt, $2^{\text {nd }}$ ed.; Cairo University Press, Cairo.

Usha, K.; Kasturi, G.M. and Hemalatha, P. (2007): Hepatoprotective effect of Hygrophila spinosa and Cassia occidentalis on carbon tetrachloride induced liver damage in experimental rats. Indian J. Clin. Biochem; 22 (2): 132-5.

Yadava, J.P.; Arya, V.; Yadava, S.; Panghal, M.; Kumar, S. and Dhan khar, S. (2012): Cassia occidentalis L: A review on its ethnobotany, phytochemistry and pharmacological profile, Fitoterapia, 81, 223-230.

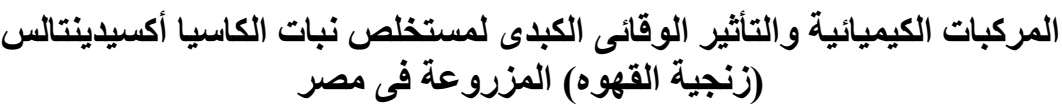

هناء محمد سبي ، محمود أحمد رمضان ، منال محمد سبل ، سارى عبل الغفار ، هبه حامد سالم

E-mail: sary64@windowslive.com_Assiut University web-site: www.aun.edu.eg

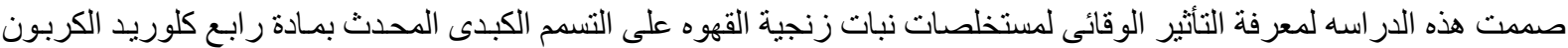

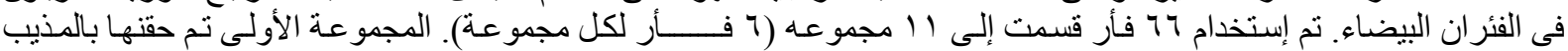
r rween)

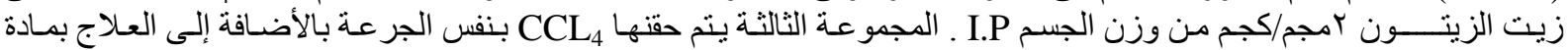
Sylimarine

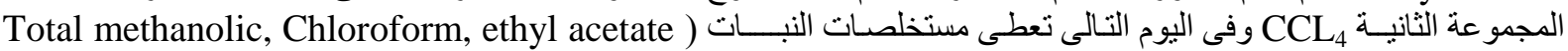

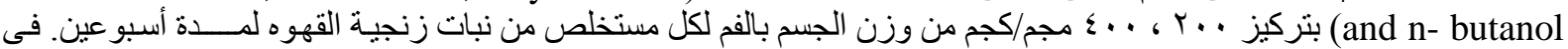

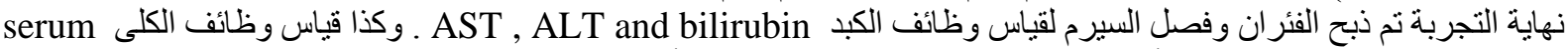
بعر creatinine

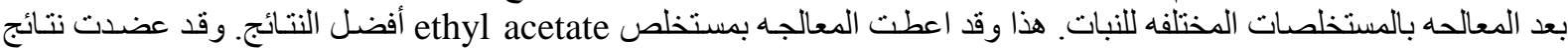

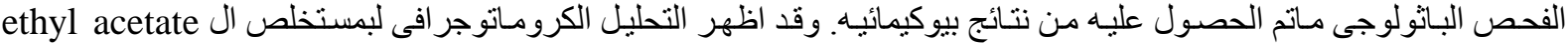

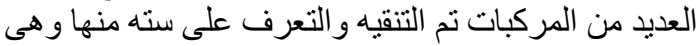
naringenin (1), quercetin (2), 1,8-dihydroxy anthraquinone (3), 1,3,8-trihydroxy anthraquinone (4), chrysoeriol-7-O-rutinoside (5) and rutin (6).

هذا وقد اعزى التأثير الكبدى الوقائى لهذه المركبات الفينوليه المستخلصه. 